\title{
Ear development and formation of grain yield in winter wheat
}

\author{
A. Darwinkel
}

Research Station for Arable Farming and Field Production of Vegetables, Postbus 430, 8200 AK Lelystad, the Netherlands

\section{Accepted: 15 April 1980}

Key words: winter wheat, grain yield, yield components, shoot age, shoot productivity.

\section{Summary}

To obtain more knowlegde about the pattern of grain production of a winter wheat crop, the effect of plant density and time of tiller emergence on grain yield per ear were studied. At harvest, ear size and ear components were ascertained; the findings are discussed in relation to ear growth and ear development during the prefloral and postfloral growing period. Detailed insight was obtained into the productivity of ear-bearing tillers and their contribution to final grain yield.

Shoot productivity decreased in denser crops: ears were smaller because spikelet differentiation, grain set and grain filling were inadequate. The time that the tiller emerged largely determined its subsequent grain yield. With later tiller initiation and emergence, fewer ears were produced. Moreover, these ears were smaller, because spikelet initiation, spikelet differentiation, grain set and grain filling were reduced. At low and moderate plant densities, the grain yield of the early-emerged tillers only slightly lagged behind that of main shoots and maximum grain yield could be achieved at moderate plant densities.

In cereal farming, high and stable grain yields are aims to be achieved. These can be best achieved by having moderate plant densities and applying correct treatments for good crop growth.

\section{Introduction}

Grain yield of cereals can be expressed as grain number multiplied by grain weight. From this it can be inferred that if high grain yields are to be attained, both grain setting and grain filling must proceed favourably. Grain yield per unit area has been found to be closely related to the number of grains, but less closely to grain weight (Evans, 1978). This relationship between grain yield and grain number was shown linearly by Evans (1978) and Spiertz (1978) and curvilinearly by Darwinkel (1978) and Fisher et al. (1977). The course of this relationship depends on growing conditions, variety and yield level. 
In the Netherlands, $18000-20000$ grains $/ \mathrm{m}^{2}$ appear to be sufficient for a potential grain yield of about 11 tonnes/ha at $15 \%$ moisture content (Darwinkel, 1978). Whether this grain number per $m^{2}$ is achieved depends on ear number and on number of grains per ear. In practice, crops with a high number of ears per $\mathrm{m}^{2}$ are undesirable for reasons of yield stability, because as crop density increases there is a greater risk of lodging, diseases and pest infestations (Parmentier, 1959). So in the Netherlands the optimum number of ears per $\mathrm{m}^{2}$ for high and stable yields seems to be 500-550. Due to variations in tillering and earing ability, this ear number can be achieved from a range of plant densities. At low densities, shoot growth must be stimulated; at a high plant density, growth must be restrained. Well-developed ears can only be expected if plant growth and plant development progress smoothly. The growth of the developing ear will be closely connected to plant growth. To encourage favourable ear development, plant growth must be stimulated. For reasons of yield stability, a critical ear number must be attained. Both these aspects are best approached by applying the adequate cultural measures to a crop stand of a moderate plant density (Laloux et al., 1975; Sturm, 1979). It is important to remember that also at moderate plant densities the formation and the productivity of tillers are essential for final grain yield.

Physiological research on cereals has been usually done in controlled environments, and has mostly been restricted to the main shoots. The purpose of this paper is to analyse the pattern of grain production of high-yielding winter wheat under field conditions. A cereal crop is a population of tillering plants; therefore ear development and yield components of individual tillers in a crop situation were studied.

\section{Analysis of yield formation}

In temperate regions, the number of seeds sown per unit area is usually less than the number of ears that must be produced per unit area to obtain high grain yields. In such crop stands, grain yield is more or less determined by ear-bearing tillers. Knowledge about the productivity of these tillers and how they can be manipulated by cultural measures is therefore important for grain production.

In spring barley (Thorne, 1962), in spring wheat (Power \& Alessi, 1978) and in winter wheat (Darwinkel, 1978, 1979), main shoots have been found to exceed ear-bearing tillers in grain yield. These differences in grain yield between main shoots and tillers were decreased by high nitrogen dressings (Power \& Alessi, 1978), suggesting that tiller development can be improved by cultural measures.

The importance of tillers for grain yield can be best ascertained in situations of maximum growth. Therefore, in our experiments, the plants had optimum conditions for development, because yield-limiting influences such as diseases, pests, lodging and mineral deficiency were prevented as far as possible. The data presented here come from a microplot plant density experiment done in 1979 . Density effects were studied at $50,100,150,200,300,400,500$ and 600 plants per $\mathrm{m}^{2}$. The layout of this experiment was comparable to a plant density experiment described earlier (Darwinkel, 1978). 


\section{A. DARWINKEL}

\section{Ear development, ear size and grain yield}

A cereal crop is a population of tillering plants. In winter wheat, the first tiller emerges as the fourth leaf appears. In temperate regions, wheat sown at the usual time (i.e. October) begins to tiller just before or during winter. The duration of tillering largely depends on temperature. In the cool spring of 1979 , tillering was prolonged, resulting in a high shoot number per plant (Table 1). With increasing plant density, fewer shoots were produced per plant, but the maximum shoot number was reached earlier (Darwinkel, 1978). This limitation in tiller formation at higher plant densities indicates early competition for light: per shoot, fewer assimilates are available for the growth of the mutually competitive organs (leaves, roots and stem apex).

It is thought that the supply of assimilates for apex growth is critical for ear development (Austin \& Jones, 1974; Gallagher \& Biscoe, 1978). Kirby (1974) found a relation between the size of apical meristem and spikelet development within the ear. These aspects of formation and development of the ear has recently been summarized by Gallagher (1979).

Many shoots can be produced per plant or per unit area, but some of them die before and during jointing. The survival of shoots depends largely on date of emergence. Moreover, at a low plant density, later-emerged tillers also produce ears, but at higher densities, ear formation is even more restricted to the older, earlier-emerged tillers (Darwinkel, 1978; Power \& Alessi, 1978).

Table 1. Number of shoots and ears per plant and per $\mathrm{m}^{2}$ and shoot fertility at various plants densities.

\begin{tabular}{rllll}
\hline Plants per $\mathrm{m}^{2}$ & $\begin{array}{l}\text { Shoot number } \\
\text { per plant }\end{array}$ & $\begin{array}{l}\text { Ear number } \\
\text { per plant }\end{array}$ & $\begin{array}{l}\text { Ear number } \\
\text { per } \mathrm{m}^{2}\end{array}$ & $\begin{array}{l}\text { Shoot fertility } \\
(\%)\end{array}$ \\
50 & 15.1 & 10.1 & 506 & 67 \\
100 & 13.1 & 6.0 & 600 & 46 \\
150 & 9.7 & 4.3 & 647 & 44 \\
200 & 10.3 & 3.4 & 674 & 33 \\
300 & 8.3 & 2.5 & 755 & 30 \\
400 & 7.0 & 2.0 & 803 & 29 \\
500 & 5.9 & 1.7 & 859 & 29 \\
600 & 5.4 & 1.4 & 837 & 26 \\
\hline
\end{tabular}

Table 2. Number of spikelets per ear and grains per fertile spikelet at various plant densities.

\begin{tabular}{rlll}
\hline Plants per $\mathrm{m}^{2}$ & $\begin{array}{l}\text { Number of } \\
\text { spikelets per ear }\end{array}$ & $\begin{array}{l}\text { Number of fertile } \\
\text { spikelets per ear }\end{array}$ & $\begin{array}{l}\text { Number of grains } \\
\text { per fertile spikelets }\end{array}$ \\
50 & 20.6 & 16.4 & 2.32 \\
100 & 20.8 & 16.5 & 2.25 \\
150 & 20.8 & 16.3 & 2.32 \\
200 & 20.9 & 16.0 & 2.13 \\
300 & 21.2 & 15.6 & 2.04 \\
400 & 21.1 & 15.5 & 1.99 \\
500 & 20.6 & 14.6 & 1.90 \\
600 & 20.3 & 14.5 & 1.90 \\
\hline
\end{tabular}


Table 3. Number of grains per ear, 1000-grain weight and grain yield per ear at various plant densities.

\begin{tabular}{rlll}
\hline Plants per $\mathrm{m}^{2}$ & $\begin{array}{l}\text { Grain number } \\
\text { per ear }\end{array}$ & $\begin{array}{l}\text { 1000-grain weight } \\
(\mathrm{g} \mathrm{DM})\end{array}$ & $\begin{array}{l}\text { Grain yield per ear } \\
(\mathrm{g} \mathrm{DM})\end{array}$ \\
50 & 38.0 & 44.6 & 1.70 \\
100 & 37.1 & 42.5 & 1.58 \\
150 & 36.2 & 41.8 & 1.51 \\
200 & 34.1 & 42.0 & 1.44 \\
300 & 31.9 & 41.4 & 1.32 \\
400 & 31.0 & 40.3 & 1.25 \\
500 & 27.7 & 39.9 & 1.11 \\
600 & 27.6 & 39.2 & 1.08 \\
\hline
\end{tabular}

Tiller survival is improved by adequate supply of nutrients, such as nitrogen (Power \& Alessi, 1978; Thorne, 1962). Therefore, Laloux et al. (1975) recommend the application of a second nitrogen gift at the end of tillering.

In our experiment, the aver age number of spikelets initiated per ear was influenced by plant density to a small extent (Table 2). The fertility of these spikelets was clearly reduced by increasing plant densities. This was reflected in a lower number of fertile spikelets per ear and also in a lower number of grains per fertile spikelet. In thin crops, more fertile spikelets and more grains per fertile spikelet were produced. This largely compensated for the lower number of ears and thus the level of grain yield was maintained to some extent. Grain number per ear was considerably lower at high plant densities, because there were fewer fertile spikelets per ear and fewer grains per fertile spikelet (Table 3). In spite of a lower grain number per ear, 1000-grain weight was also lower at higher densities, causing a considerable decrease in grain yield per ear. Similar results were found by Willey \& Holliday (1971). This reduced productivity of shoots in dense crops probably has several causes: fewer assimilates are produced per shoot, fewer storage resources are available to be translocated and the partitioning of dry matter between grains and the rest of the plant is unfavourable.

Table 4. Shoot fertility, number of spikelets and grains per fertile spikelet in main shoots (ms) and sequental tillers $\left(t_{1}, \ldots t_{z}\right)$ at 100 plants per $\mathrm{m}^{2}$.

\begin{tabular}{lllll}
\hline $\begin{array}{l}\text { Shoot } \\
\text { sequence }\end{array}$ & $\begin{array}{l}\text { Shoot } \\
\text { fertility }\end{array}$ & $\begin{array}{l}\text { Spikelet } \\
\text { number }\end{array}$ & $\begin{array}{l}\text { Number of } \\
\text { fertile spikelets }\end{array}$ & $\begin{array}{l}\text { Grains per } \\
\text { fertile spikelet }\end{array}$ \\
$\mathrm{ms}$ & 96 & 21.4 & 18.3 & 2.41 \\
$\mathrm{t}_{1}$ & 94 & 21.7 & 18.0 & 2.35 \\
$\mathrm{t}_{2}$ & 92 & 21.7 & 17.6 & 2.31 \\
$\mathrm{t}_{3}$ & 78 & 20.7 & 16.3 & 2.25 \\
$\mathrm{t}_{4}$ & 52 & 20.0 & 15.2 & 2.11 \\
$\mathrm{t}_{5}+\mathrm{t}_{6}$ & 29 & 19.8 & 14.7 & 2.05 \\
$\mathrm{t}_{7}{ }^{*}$ & 21 & 19.8 & 14.8 & 2.08 \\
\hline
\end{tabular}

* And all subsequent tillers. 


\section{A. DARWINKEL}

Table 5. Grain number, 1000 grain weight, grain yield and harvest index of main shoots (ms) and sequential tillers $\left(\mathrm{t}_{1}, \ldots, \mathrm{t}_{\mathrm{z}}\right)$ at 100 plants per $\mathrm{m}^{2}$.

\begin{tabular}{lllll}
\hline $\begin{array}{l}\text { Shoot } \\
\text { sequence }\end{array}$ & $\begin{array}{l}\text { Grain } \\
\text { number }\end{array}$ & $\begin{array}{l}\text { 1000-grain weight } \\
(\mathrm{g} \mathrm{DM})\end{array}$ & $\begin{array}{l}\text { Grain yield } \\
(\mathrm{g} \mathrm{DM})\end{array}$ & $\begin{array}{l}\text { Harvest } \\
\text { index }\end{array}$ \\
$\mathrm{ms}$ & 44.0 & 44.1 & 1.94 & 44.8 \\
$\mathrm{t}_{1}$ & 42.4 & 43.0 & 1.83 & 45.6 \\
$\mathrm{t}_{2}$ & 40.6 & 42.1 & 1.68 & 45.5 \\
$\mathrm{t}_{3}$ & 36.5 & 42.7 & 1.56 & 46.7 \\
$\mathrm{t}_{4}$ & 32.0 & 41.6 & 1.34 & 46.3 \\
$\mathrm{t}_{5}+\mathrm{t}_{6}$ & 30.0 & 41.2 & 1.25 & 45.6 \\
$\mathrm{t}_{7}{ }^{*}$ & 30.9 & 41.1 & 1.27 & 45.3 \\
\hline
\end{tabular}

* And all subsequent tillers.

\section{Shoot age, ear development and grain production}

During the tillering phase many shoots are produced sequentially. These shoots can be classified according to age. At the stem elongation stage of the main shoot, large differences in developmental stage (Stern \& Kirby, 1979) and in weight (Power \& Alessi, 1978) can be recorded between the shoots. The oldest shoots (i.e. those that emerge early), especially the main shoots, were the best developed (Table 4). The lag in development of young shoots that emerge later is partly compensated for by their accelerated development; this will largely be achieved by producing fewer leaves per stem (Stern \& Kirby, 1979). According to the findings of Stern \& Kirby (1979), the initiation of spikelets was only slightly affected, but all sequential processes in shoot development had suffered in lateremerged shoots (Table 4).

The formation of ears, indicated as shoot fertility, was rather complete for main shoots and for early-emerged tillers at low densities; almost all the lateemerged tillers died. The unfavourable ear development in young tillers was also expressed by fewer fertile spikelets per ear and fewer grains per spikelet. Table 5 shows that grain yield per ear was considerably lower in younger shoots, because the number of grains per ear and the 1000-grain weight both decreased. The proportion of aerial dry matter, accumulated in grains ( $=$ harvest index), was not influenced by shoot age when the density was 100 plants per $\mathrm{m}^{2}$ and a closed crop canopy was achieved after heading. In thin crops that incompletely covered the soil, the harvest index decreased the later the shoots emerged (Darwinkel, 1979).

The effect of shoot age on ear development and the sequential ear yield was even more pronounced at higher plant densities. Tables 4 and 5 show that at 100 plants per $\mathrm{m}^{2}$, the oldest ear-bearing tillers produced well and only slightly lagged behind the main shoots. At high plant densities, these tillers were less important, as can be seen in Fig. 1. However, it must be noted that many lateremerged tillers produced ears at a low plant density, but not at a high plant density (Table 1).

The reduction in grain yield of tillers compared to main shoots is not fully 


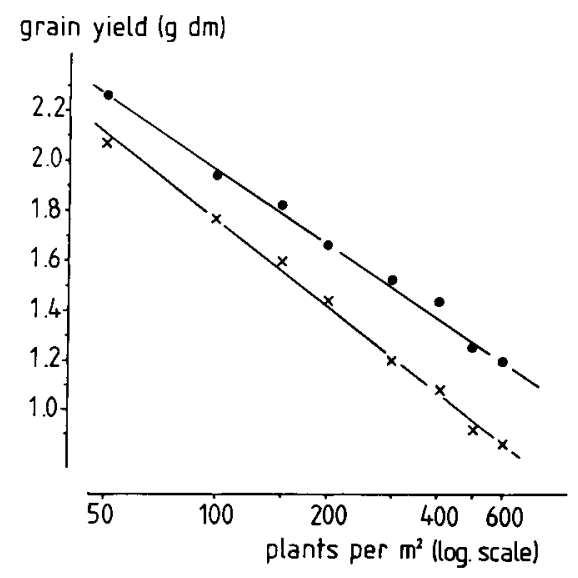

Fig. 1. Grain yield of main shoots $(\bullet)$ and of the two oldest ear-bearing tillers $(X)$ at increasing plant densities.

understood. An inadequate supply of assimilates to the developing ear and subsequently to the grains can be restrictive. The production of assimilates necessary for optimal shoot and ear growth might be insufficient in young earbearing tillers, because the development of these tillers is accelerated and their position in the crop stand is less favourable. As a result, fewer grains will be produced per ear, but even at a lower grain number, the grains were not better filled (Table 5). The consequent reduction in grain yield in younger shoots could

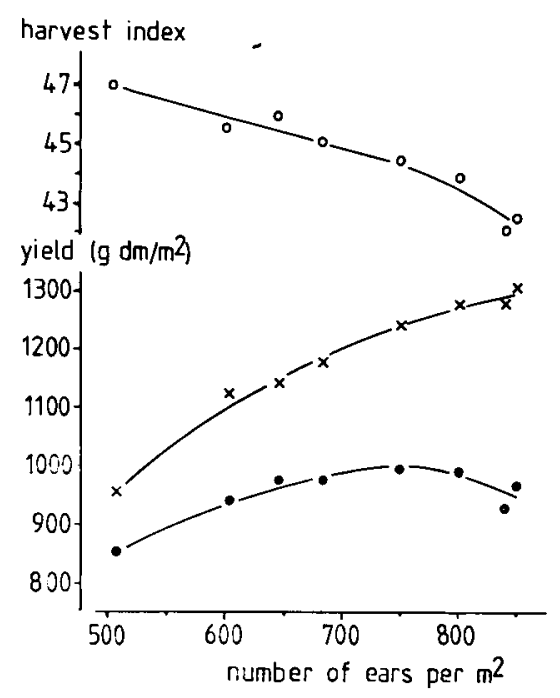

Fig. 2. Dry matter yields of grains $(\bullet)$ and straw + chaff $(X)$ and harvest index $(=$ ratio grain yield/total aerial yield) at increasing ear number per $\mathrm{m}^{2}$. 


\section{A. DARWINKEL}

perhaps be explained in terms of the results obtained by Ellen \& Spiertz (1980), who found that differences in ear yield were not dependent on grain growth rate, but on the number of grains, if growing conditions are the same. Moreover, the internal hormonal balance in the plant may also be unfavourable for the development of ear-bearing tillers.

\section{Practical relevance}

In cereal farming, both grain yield and yield stability have to be considered. Total aerial dry matter yield continues to increase with increasing plant density. To achieve complete light interception, dense crop stands are best. However, dense cereal crops are risky because of the increased incidence of lodging, fungal diseases and pests. In the Netherlands 500 - 550 ears per $\mathrm{m}^{2}$ seems to be the optimal density for obtaining high and stable grain yields in winter wheat.

In denser crops, ear size decreases, but straw length increases; grain yield per ear decreases as does also stem weight but to a less degree. Consequently, harvest index is reduced. At higher densities, a higher proportion of the dry matter produced is used for the growth of straw and chaff and therefore grain yield approaches an asymptote (Darwinkel, 1978). Moreover, at high plant densities producing more than 800 ears per $\mathrm{m}^{2}$, the harvest index can even decrease to such and extent that grain yield is reduced (Fig. 2).

The best conditions for grain production are achieved if crop growth proceeds undisturbed. Then, tiller formation and growth of the developing ear proceed favourably. In crop stands that produce the optimal number of ears per $\mathrm{m}^{2}$, grain yield is determined by the high productivity of both, main shoots and earlyemerged tillers. Under good growing conditions, the two first emerged tillers are very productive and are outyielded by main shoots for only about $10 \%$. In the Netherlands, the desired number of ample 500 ears per $\mathrm{m}^{2}$ can be best achieved from a density of $200-250$ plants per $\mathrm{m}^{2}$.

\section{References}

Austin, R. B. \& H. G. Jones, 1974. The physiology of wheat. Rep. Pl. Breed. Inst., Cambridge 20-66.

Darwinkel, A., 1978. Patterns of tillering and grain production of winter wheat at a wide range of plant densities. Neth. J. agric. Sci. 26: 383-398.

Darwinkel, A., 1979. Ear size in relation to tiller emergence and crop density. In: J. H. J. Spiertz \& Th. Kramer (Ed.), Crop phyisology and cereal breeding, Proc. Eucarpia Workshop (Wageningen, 1978) 10-15.

Ellen, J. \& J. H. J. Spiertz, 1980. Effects of rate and timing of nitrogen dressings on grain yield formation of winter wheat ( $T$. aestivum $L$.). In press.

Evans, L. T., 1978. The influence of irradiance before and after anthesis on grain yield and its components in microcrops of wheat grown in a constant daylength and temperature regime. Field Crops. Res. 1: 5-19.

Fisher, R. A., I. Aquilar \& D. R. Laing, 1977. Post-anthesis sink size in high yielding dwarf wheat: Yield response to grain number. Aust. J. agric. Res. 28: 165-175. 


\section{EAR DEVELOPMENT AND GRAIN YIELD OF WINTER WHEAT}

Gallagher, J. N,. 1979. Ear development: processes and prospects. In: J. H. J. Spiertz \& Th. Kramer (Ed.), Crop physiology and cereal breeding. Proc. Eucarpia Workshop (Wageningen, 1978) 3-9.

Gallagher, J. N. \& P. V. Biscoe, 1978. A physiological analysis of cereal yield. II. Partitioning of dry matter. Agric. Progr. 53: 51-70.

Kirby, E. J. M., 1974. Ear development in spring wheat. J. agric. Sci., Camb. 82: 437-447.

Laloux, R., J. Poelaert \& A. Falisse, 1975. Stikstofbemesting bij graangewassen. Landbouwtijdschrift 28: 1155-1184.

Parmentier, G., 1959. Azote et oïdum. Parasitica 29: 70-71.

Power, J. F. \& J. Alessi, 1978. Tiller development and yield of standard and semi-dwarf spring wheat varieties as affected by nitrogen fertilizer. J. agric. Sci., Camb. 90: 97-108.

Spiertz, J. H. J., 1978. Grain production and assimilate utilization of wheat in relation to cultivar characteristics, climatic factors and nitrogen supply. Agric. Res. Rep. 881: 1-32.

Stern, W. R. \& E. J. M. Kirby, 1979. Primordium initiation at the shoot apex in four contrasting varieties of spring wheat in response to sowing date. J. agric. Sci., Camb. 93: 203-215.

Sturm, H., 1979. Wechselbeziehungen zwischen Mineraldüngung und phytomedizinischen Massnahmen. Kali-Briefe (Büntehof) 14: 471-486.

Thorne, G. N., 1962. Survival of tillers and distribution of dry matter between ear and shoot of barley varieties. Ann. Bot. 26: 37-54.

Willey, R. W. \& R. Holliday, 1971. Plant population, shading and thinning studies in wheat. J. agric. Sci., Camb. 77: 453-461. 